Asian J. Med. Biol. Res. 2016, 2 (4), 672-677; doi: 10.3329/ajmbr.v2i4.31013

\author{
Asian Journal of \\ Medical and Biological Research \\ ISSN 2411-4472 (Print) 2412-5571 (Online) \\ www.ebupress.com/journal/ajmbr
}

\title{
Article \\ Water requirement analysis of three strawberry cultivars by using bucket-type lysimeter and its comparative study
}

\author{
Md. Hafizul Islam ${ }^{1}$, Md. Erfanul Haq ${ }^{2 *}$, Prajna Paramita Paul ${ }^{1}$, Amitave Paul $^{1}$ and Ziaul Hoque ${ }^{3}$ \\ ${ }^{1}$ Department of Agricultural and Industrial Engineering, Hajee Mohammad Danesh Science and Technology \\ University, Dinajpur- 5200, Bangladesh \\ ${ }^{2}$ Department of Soil Science, Bangladesh Agricultural University, Mymensingh-2202, Bangladesh \\ ${ }^{3}$ Department of Environmental Science, Bangladesh Agricultural University, Mymensingh-2202, Bangladesh
}

*Corresponding author: Md. Erfanul Haq, Department of Soil Science, Bangladesh Agricultural University, Mymensingh-2202, Bangladesh. E-mail: erfanulhaq.bd@gmail.com

Received: 21 November 2016/Accepted: 19 December 2016/ Published: 29 December 2016

\begin{abstract}
An experiment was carried out from November, 2014 to February, 2015 at Dinajpur, Bangladesh to quantify the total water requirement of Strawberry for three indigenous cultivars RU-1, RU-2 and RU-3by using 12 " $\times 11.5$ " Bucket-Type Lysimeter. Water requirement in zero evaporation condition for RU-1, RU-2 and RU-3 were $86.25 \pm 0.23,49.22 \pm 0.31$ and $73.42 \pm 0.42 \mathrm{~mm}$ respectively, which were significantly different $(\mathrm{p}<0.01)$. After adding field evaporation total water requirement RU-1, RU-2 and RU-3 were $351.45 \pm 0.23,324.42 \pm$ 0.31 and $338.61 \pm 0.42 \mathrm{~mm}$ respectively.ET ${ }_{0}$ (Potential evapotranspiration)value ranged between3.21-4.56 $\left(\mathrm{mm} /\right.$ day) while seasonal $\mathrm{ET}_{0}$ was approximately $457(\mathrm{~mm} / \mathrm{season}) \mathrm{ET}_{\mathrm{c}}$ (Evapotranspiration) value measured by using $\mathrm{K}_{\mathrm{c}}$ (Crop coefficient) value and equations provided by FAO, (2016a, b) viz. 324.24 (mm/season). As plant only uses less than $1 \%$ of its total water uptake for metabolic use, Crop water requirement (CWR) can be easily represented by $\mathrm{ET}_{\mathrm{c}}$. However our CWR value is in line with the theoretical $\mathrm{ET}_{\mathrm{c}}$ which clearly indicates level of accuracy. Therefore, it is highly recommendable for the local Commercial Strawberry growers to get robust yield.
\end{abstract}

Keywords: crop water requirement; lysimeter; potential evapotranspiration; crop coefficient; strawberry; Bangladesh

\section{Introduction}

Water for Agriculture is becoming rare due to rise of water necessity from numerous areas and currently global water requirement has increased six times than the last century (IWMI, 2011). Irrigation is probably the most important use of water all over the world. Water uptake for irrigation are nearly $70 \%$ of the total withdrawn for human uses followed by industrial use (20\%) and municipal (10\%) use (Cosgrove, 2014). Inadequate knowledge for specific Crop Water Requirement (CWR) may lead to inappropriate use of water and higher input cost for growers. CWR is defined as the total amount of water that is lost via Evapotranspiration (ET) process. CWR analysis is essential for the design and operation of soil and water management policies (Igbadun 2012). For decades lysimeters have been used to measure ET, CWR and Crop co-efficient $\left(K_{c}\right)$ for a cultivar of crops. Different designs for lysimeter has been invented to achieve maximum accuracy as well as Cost efficiency (Howell et al., 1985; Marek et al., 1988; Bergstrom, 1990; Allen and Fisher, 1990; Young et al., 1996; Yang et al., 2000). Hence the reasons behind selecting Bucket type Lysimeter are portability, easy access and Cost efficiency.

Strawberry (Fragaria ananassa Duch.) is one of the most delicious and fragrantly sweet flavoured fruits of the world, very popular in many countries (Sharma and Sharma, 2004). Strawberry is becoming a popular crop among Bangladeshi growers after its successful field performance and higher market value for its consumers 
(Rahman et al., 2013). Still Bangladeshi growers is quite unknown to its cultivation technique especially irrigation schedule and eventually there is only a handful research on CWR analysis for strawberry in the context of Bangladesh. Besides, commercials are facing several problems such as less sweetness, short shelf-life and damage during transportation. Efficient irrigation for optimum fruit quality is really necessary (Fallahi $e t$ $a l ., 2010)$ for commercial strawberry production in Bangladesh. Especially strawberry is very much sensitive to water stress (Lozano et al., 2016). Thus the objectives of the study is to determine CWR of strawberry and its comparison with Theoretical value.

\section{Materials and Methods}

The experiment was carried out at Faculty of Engineering, Hajee Mohammad Danesh Science and Technology University (HSTU), Dinajpur, Bangladesh; $25.63^{\circ}$ North latitude, $88.64^{\circ}$ East longitude during November, 2014 to February, 2015.The climatic conditions of the study area were characterized by an annual rainfall of 1979 $\mathrm{mm}(77.9 \mathrm{inch})$ and the mean annual temperature of $25^{\circ} \mathrm{C}\left(77^{\circ} \mathrm{F}\right)$ and monthly means varying between $18^{\circ} \mathrm{C}$ $\left(64^{\circ} \mathrm{F}\right)$ in January and $29^{\circ} \mathrm{C}\left(84^{\circ} \mathrm{F}\right)$ in August (Table 1). All weather data were collected from Dinajpur weather Station, Bangladesh.

\subsection{Lysimeter preparation and experimental design}

A non-weighing bucket type lysimeter was designed by using a bucket of 12 inch height \& 11.5 inch diameter. Four holes were made at the bottom of the bucket to collect the percolated water. The percolated water was collected by a pot which has a strong covering. From the farm field of HSTU the sandy loam soil was collected and standard fertilizer doses applied for strawberry cultivation (BARC 2012) i.e. 40gm Urea, TSP and MOP in every bucket. Large size gravels, small size gravels and sand were placed respectively from bottom of the each bucket followed by proper Soil Mixture. The soil of the studied area is classified as sandy loam (USDA classification), with $60 \%$ sand, $27 \%$ silt and $13 \%$ clay. The arrangement of soil in the bucket was gravel (both small and moderate), sand, sandy loam \& then sand respectively (Figure 1). A plastic funnel was attached to the bottom of bucket with the help of sugar glue. Seven days old healthy and disease free strawberry plants of RU1, RU-2 and RU-3 were collected from the Rajshahi University, Bangladesh. With great care planting have completed through making 2-3 cm deep hole manually. Mulching has done to prevent capillary raise of water and polythene cover was used to create zero evaporation condition and to control entry of rain water into pot. This plastic covering was fastened tightly with a rope to the bucket Other Intercultural Operations weeding alone with pesticide application were done accordingly. 50 WP Carbendazim @ 200 mm/plant were applied on 30 December, 2014. Drip irrigation system was applied by using pipe with regulator to control water movement. Irrigation continued from $20^{\text {th }}$ December, 2014 to $24^{\text {th }}$ February through changing water flow as required.

As stated in the objectives, the main purpose of this study was to investigate the $\mathrm{ET}_{\mathrm{c}}, \mathrm{ET}_{0}$ andto compare. Nine buckets were used for3replication of each cultivars. Single plant was planted in every single bucket and all strawberry plant quality were similar. The seasonal water requirement is computed by adding measured quantities of irrigation water, effective rainfall received during the season and the contribution of moisture from the soil. Field water balanced may be expressed by the following relationship.

$W R=I R+E R+\sum_{i=1}^{n} \frac{M b i-M e i}{100} \times A i \times D i-P \ldots \ldots . .[1]$

Where,

$\mathrm{WR}=$ seasonal water requirement $(\mathrm{mm}) ; \mathrm{IR}=$ total irrigation water applied(mm); ER $=$ seasonal effective rainfall $(\mathrm{mm}) ; \mathrm{Mbi}=$ moisture percentage of the beginning of the season in the ith layer of the soil; Mei = moisture percentage at the end of the season in the ith layer of the soil; $\mathrm{Ai}=$ apparent specific gravity of the ith layer of the soil; $\mathrm{Di}=$ depth of ith layer of the soil with in the root zone $(\mathrm{mm}) ; \mathrm{n}=$ number of soil layer in the root zone $\mathrm{D} ; \mathrm{P}=$ percolation;

\subsection{Seasonal Crop Coefficient Calculation}

The Blaney-Criddle equation is a relatively simplistic method for calculating potential evapotranspiration.

$\mathrm{ET}_{0}$ can be determined by following equations (FAO, 2016a)

$\left.\mathrm{ET}_{0}=\mathrm{P} *\left(0.46 \mathrm{~T}_{\text {mean }}+8\right) \ldots \ldots \ldots \ldots . . .2\right]$

Where, $\mathrm{ET}_{0}=$ Potential Evapotranspiration $(\mathrm{mm}$ of water per day); $\mathrm{P}=$ monthly percentage of total day time hours of year; $\mathrm{T}_{\text {mean }}=$ mean daily temperature $\left({ }^{\circ} \mathrm{C}\right)$

$\mathrm{ETc}=\mathrm{K}_{\mathrm{c}} * \mathrm{ETo} \ldots \ldots \ldots \ldots[3]$ 
Where, $\mathrm{K}_{\mathrm{c}}=$ crop coefficient; ETc $=$ Evapotranspiration or Consumptive use of water.

SPSS and Microsoft Excel program 2013 were used to process and analyze the data. DMRT was done to test was done to check the level of significance.

\section{Results and Discussion}

\subsection{Total supplied and percolated water}

Growers of the study area perceive that strawberry is very sensitive to water stress. The water was supplied to every reference crop according to their need. Amount of water of the soil surface have been checked regularly. So water was supplied only if the soil found dry. Total supplied water and Percolated water varied from plant to plant because of growth and cultivar (Table 2). Maximum water was supplied in R1 of RU-3 (7430 ml) whereas minimum was found in R3 of RU-1 $(6510 \mathrm{ml})$. Similar data was observed in case of percolation.

\subsection{Corp water requirement (CWR)}

From equation [1] average water requirement for RU-1, RU-2 and RU-3 were found as follows; 86.25, 49.22 and $73.42 \mathrm{~mm}$ (Table 4). Significant difference were found among the varieties. The soil surface of the plant were covered with polyethylene. So amount of evaporation was tends to zero. But in field level evaporated water must take into account to calculate total crop water requirement. Total water requirement for RU-1, RU-2 and RU-3 (Figure 2) were estimated $351.45 \pm 0.23,324.42 \pm 0.31$ and $338.61 \pm 0.42 \mathrm{~mm}$ respectively. Previous scientific research shows a wide range of water requirement analysis, ranging between 300 and $787 \mathrm{~mm}$ (Serrano et al., 1992; Trout and Gartung, 2004; Hanson and Bendixen, 2004; Strand, 2008). Lozano et al. (2016) used drainage lysimeters in Sabrina trial and seasonal crop evapotranspiration ranged from 430 to 453 $\mathrm{mm}$, whereas in Antilla it reached $352 \mathrm{~mm}$. The reason behind this slight difference with our experiment is may be because geological, climatic and cultivar difference.

\section{3. $\mathbf{E T}_{\mathbf{0}}$ (Potential evapotranspiration)}

$\mathrm{ET}_{0}$ was measured by using Blaney-Criddle equation [2] where $\mathrm{p}$ value for $25^{\circ}$ North latitude was obtained from FAO, (2016c). $\mathrm{ET}_{0}$ (mm/season) was approximately $457 \mathrm{~mm} / \mathrm{season}$. Clark et al., (1996) reported that for three consecutive years 1988-1991 $\mathrm{ET}_{0}$ values of strawberry ranged between 457-537 (mm/season) in Drip irrigation system. Lozano et al. (2016) concluded that estimated $\mathrm{ET}_{\mathrm{o}}$ over the course of the growing season was523 (mm/season).

\section{4. $\mathrm{ET}_{\mathrm{c}}$ (Crop evapotranspiration)}

$\mathrm{ET}_{\mathrm{c}}$ value was measured by using [3] equation and $\mathrm{K}_{\mathrm{c}}$ value of strawberry at different stages. FAO, (2016b) shows a wide range of $\mathrm{K}_{\mathrm{c}}$ values for non-stressed, well-managed strawberry cultivation in sub humid climates i.e. 0.45 (Init. stage), 0.80 (Dev. stage), 0.80 (mid. stage) and 0.75 (late stage). Using these values for 4 different month November to February the estimated ET $_{\mathrm{c}}$ was 324.24 (mm/ season). As plant only uses less than $1 \%$ of its total water uptake for metabolic use, Crop water requirement (CWR) can be easily represented by $\mathrm{ET}_{\mathrm{c}}$. The acquired CWR $(351.45 \pm 0.23,324.42 \pm 0.31$ and $338.61 \pm 0.42 \mathrm{~mm} /$ season $)$ values were compared with calculated $\mathrm{ET}_{\mathrm{c}}$ value $(324.24 \mathrm{~mm} /$ season) which clearly indicates that our findings is in line with the theoretical $\mathrm{ET}_{\mathrm{c}}$ estimation. However the reason behind this slight difference maybe be because subtropical environment and difference between Cultivars.

Table 1. Weather parameters, $\mathbf{E T}_{\mathbf{0}}$ and $\mathrm{ET}_{\mathrm{c}}$ in four months.

\begin{tabular}{|c|c|c|c|c|c|c|c|c|}
\hline \multirow[b]{2}{*}{ Month } & \multicolumn{6}{|c|}{ Weather parameters } & \multirow{2}{*}{$\begin{array}{l}\mathbf{E T}_{0} \\
(\mathbf{m m} / \text { day })\end{array}$} & \multirow{2}{*}{$\begin{array}{l}\mathbf{E T}_{\mathrm{C}} \\
(\mathrm{mm} / \text { day })\end{array}$} \\
\hline & $\begin{array}{l}\text { Rainfall } \\
\text { (mm) }\end{array}$ & $\begin{array}{l}\text { Mean } \\
\text { maximum } \\
\text { air } \\
\text { temperature } \\
\left({ }^{\circ} \mathrm{C}\right)\end{array}$ & $\begin{array}{l}\text { Mean } \\
\text { minimum } \\
\text { air } \\
\text { temperature } \\
\left({ }^{\circ} \mathrm{C}\right)\end{array}$ & $\begin{array}{l}\text { Mean } \\
\text { average } \\
\text { relative } \\
\text { humidity } \\
(\%)\end{array}$ & $\begin{array}{l}\text { Mean } \\
\text { evaporation } \\
(\mathrm{mm}) / \text { day }\end{array}$ & $\begin{array}{l}\text { Mean } \\
\text { sun } \\
\text { shine } \\
\text { (hrs) }\end{array}$ & & \\
\hline November & 00.00 & 13.50 & 09.85 & 79.64 & 02.32 & 06.02 & 3.21 & 1.44 \\
\hline December & 41.00 & 9.98 & 07.02 & 81.87 & 1.980 & 5.820 & 3.10 & 2.48 \\
\hline January & 0.10 & 16.24 & 11.68 & 82.02 & 1.09 & 4.20 & 3.89 & 3.12 \\
\hline February & 12 & 20.31 & 13.33 & 76.19 & 03.01 & 06.83 & 4.56 & 3.42 \\
\hline
\end{tabular}


Table 2. Total Amount of Supplied Water (in $\mathbf{~ m m}$ ) and percolated water (in mm).

\begin{tabular}{|c|c|c|c|c|c|c|}
\hline Cultivar & Replication & $\begin{array}{l}\text { Area of } \\
\text { Bucket } \\
\left(\text { in } \mathbf{~ m}^{2}\right)\end{array}$ & $\begin{array}{l}\text { Supplied } \\
\text { Water } \\
\left(\text { in } \mathbf{m}^{3}\right)\end{array}$ & $\begin{array}{l}\text { Supplied } \\
\text { Water(in mm) } \\
\text { Water/Area } \\
\end{array}$ & $\begin{array}{l}\text { Percolated } \\
\text { Water } \\
\left(\text { in } \mathrm{m}^{3}\right) \\
\end{array}$ & $\begin{array}{l}\text { Percolated } \\
\text { Water(in mm) } \\
\text { Water/Area } \\
\end{array}$ \\
\hline \multirow{4}{*}{ RU-1 } & R1 & 0.27 & 0.00654 & 24.222 & 0.000396 & 1.467 \\
\hline & R2 & 0.27 & 0.00652 & 24.148 & 0.000393 & 1.456 \\
\hline & R3 & 0.27 & 0.00651 & 24.111 & 0.00039 & 1.444 \\
\hline & R1 & 0.27 & 0.0054 & 20.000 & 0.000826 & 3.059 \\
\hline \multirow[t]{3}{*}{ RU-2 } & R2 & 0.27 & 0.0052 & 19.259 & 0.000822 & 3.044 \\
\hline & R3 & 0.27 & 0.0053 & 19.630 & 0.000823 & 3.048 \\
\hline & R1 & 0.27 & 0.00743 & 27.519 & 0.001251 & 4.633 \\
\hline \multirow[t]{2}{*}{ RU-3 } & R2 & 0.27 & 0.00741 & 27.444 & 0.001259 & 4.663 \\
\hline & R3 & 0.27 & 0.00743 & 27.519 & 0.001247 & 4.619 \\
\hline
\end{tabular}

Table 3. Soil Moisture Content, Depth of root zone, Effective Rainfall analysis.

\begin{tabular}{lllllll}
\hline Cultivar & Replication & $\begin{array}{l}\text { Initial } \\
\text { Moisture } \\
\text { Content }(\%)\end{array}$ & $\begin{array}{l}\text { Final } \\
\text { Moisture } \\
\text { Content }(\%)\end{array}$ & $\begin{array}{l}\text { Depth of soil } \\
\text { root zone } \\
\text { (mm) }\end{array}$ & $\begin{array}{l}\text { Apparent } \\
\text { Specific } \\
\text { Gravity }\end{array}$ & $\begin{array}{l}\text { Effective } \\
\text { Rainfall } \\
\text { (mm) }\end{array}$ \\
\hline \multirow{3}{*}{ RU-1 } & R1 & 2.83 & 23.87 & 63.21 & 2.6 & 0 \\
& R2 & 2.87 & 23.96 & 62.85 & 2.6 & 0 \\
& R3 & 2.84 & 23.92 & 62.92 & 2.6 & 0 \\
RU-2 & R1 & 2.74 & 22.49 & 42.09 & 2.6 & 0 \\
& R2 & 2.72 & 22.41 & 42.46 & 2.6 & 0 \\
& R3 & 2.73 & 22.35 & 41.84 & 2.6 & 0 \\
RU-3 & R1 & 2.83 & 24.07 & 49.49 & 2.6 & 0 \\
& R2 & 2.81 & 24.28 & 50.34 & 2.6 & 0 \\
\hline
\end{tabular}

Table 4. Water Requirement analysis.

\begin{tabular}{llll}
\hline Cultivar & water requirement $(\mathbf{m m})$ & Evaporation $(\mathbf{m m} / \mathbf{s e a s o n})$ & Standard Deviation \\
\hline RU-1 & $86.25^{* *}$ & 265.2 & 0.23 \\
RU-2 & $59.22^{* *}$ & 265.2 & 0.31 \\
RU-3 & $73.41^{* *}$ & 265.2 & 0.42 \\
\hline
\end{tabular}

(**) Indicates significantly different at $1 \%$ level of probability by DMRT.

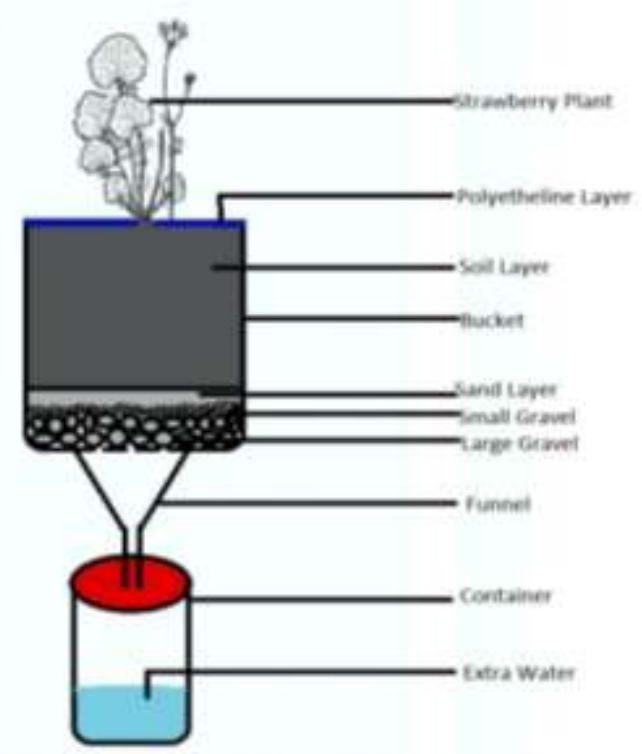

Figure 1. Direct method for computing seasonal crop water requirement. 


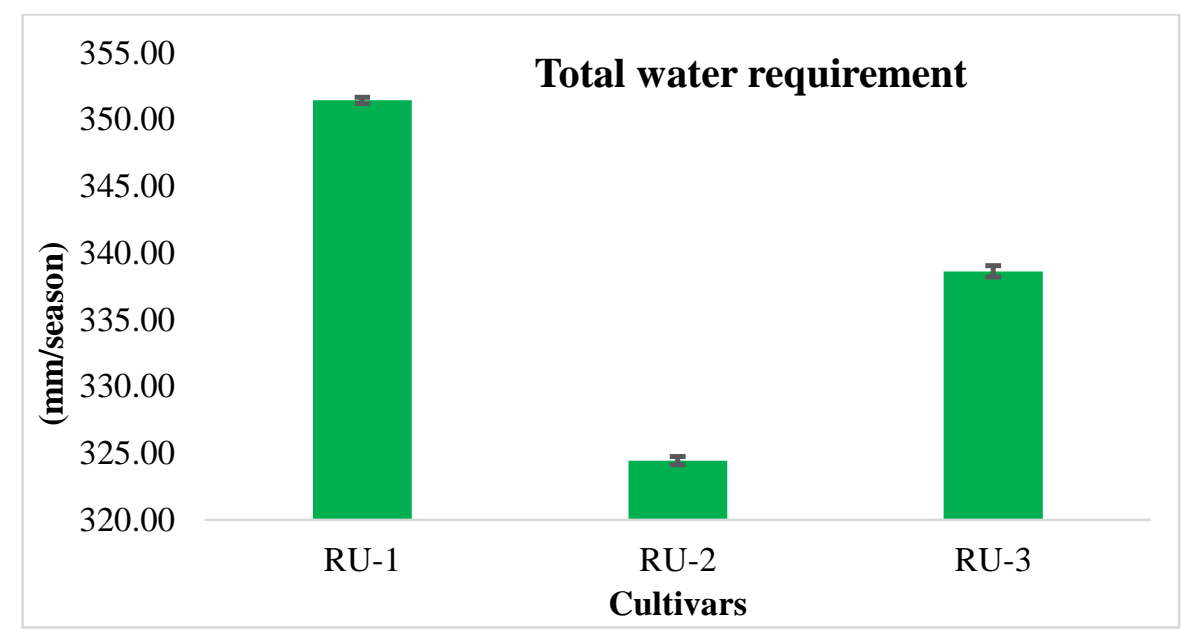

Figure 2. Total Water requirement of RU-1, RU-2, RU-3 cultivars.

\section{Conclusions}

This experiment presents the amount of water requirement for strawberry in drip irrigation system for three different cultivar. The irrigation was supplied locally made and very cheap irrigation system. With the use of such lysimeter, fundamental information could be acquired with a relatively economical system and a minimum of maintenance. The system was able to measure the soil water content mean values between the established ranges throughout the total growing period. Evaporation of soil surface was controlled and entry of rain water into the plant was totally controlled. With supplying the irrigation, others operation like weeding, application of fertilizers, herbicides, pesticides etc. were done properly. Since the crop water requirement values were determined matching the local conditions of soil, plant, and environment, they are more accurate than the standard ones. Therefore, it is highly recommendable for the local Commercial Strawberry growers to get robust yield.

\section{Conflict of interest}

None to declare.

\section{References}

Allen RG and DK Fisher, 1990. Low-cost electronic weighing lysimeters. Transactions of the ASAE, 33: 18231833.

BARC, 2012. Fertilizer Recommendation Guide, Bangladesh Agricultural Research Council (BARC), Dhaka, Bangladesh. 274p

Bergström L, 1990. Use of lysimeters to estimate leaching of pesticides in agricultural soils. Environmental Pollution, 67: 325-347.

Clark GA, EE Albregts, CD Stanley, AG Smajstrla and FS Zazueta, 1996. Water requirements and crop coefficients of drip-irrigated strawberry plants. Transactions of the ASAE, 39: 905-913.

Cosgrove WJ and FR Rijsberman 2014. World water vision: making water everybody's business. Routledge, New York, USA.

Fallahi E, D Neilsen, GH Neilsen, B Fallahi and B Shafii, 2010. Efficient Irrigation for Optimum Fruit Quality and Yield in Apples. Hort. Sci., 45: 1616-1625

FAO, 2016a. Crop evapotranspiration - Guidelines for computing crop water requirements. Available: http://www.fao.org/docrep/s2022e/s2022e07.htm.

FAO, 2016b. Crop evapotranspiration - Guidelines for computing crop water requirements. Available: http://www.fao.org/docrep/X0490E/x0490e0b.htm\#chapter6etcsinglecropcoe fficient $(\mathrm{kc}) \cdot \mathrm{htm}$.

Gavilán P, N Ruiz and D Lozano, 2015. Daily forecasting of reference and strawberry crop evapotranspiration in greenhouses in a Mediterranean climate based on solar radiation estimates. Agric. Water Manage. 159: 307-317.

Hanson B and W Bendixen, 2004. Drip irrigation evaluated in Santa Maria Valley strawberries. Calif. Agric. 58: 48-53. 
Howell TA, RL McCormick, and CJ Phene, 1985. Design and installation of large weighing lysimeters. Transactions of the ASAE, 28: 106-112.

Igbadun HE, 2012. Irrigation Scheduling Impact Assessment MODEL (ISIAMOD): A decision tool for irrigation scheduling. Indian J. Sci. Technol., 5: 3090-3099.

IWMI, 2011. IWMI Annual report 2010: A vision Water for a Food-secure World, International water Management Institute, Colombo, Srilanka. P.26

Lozano D, N Ruiz, and P Gavilán, 2016. Consumptive water use and irrigation performance of strawberries. Agricultural Water Management, 169: 44-51.

Marek TH, AD Schneider, TA Howell and LL Ebeling, 1988. Design and construction of large weighing lysimeters. Transactions of the ASAE, 31: 477-484.

Rahman MM, MM Rahman, MM Hossain, MAK Mian and QA Khaliq, 2013. Characterization and field performance of 15 Strawberry germplasm under Bangladesh conditions. SAARC J. Agri., 11: 81-94.

Serrano L, X Carbonell, R Save, O Marfà and J Pẽnuelas, 1992. Effects of irrigation regimes on the yield and water use of strawberry. Irrigation Sci., 13: 45-48.

Sharma RR and VP Sharma, 2004. The Strawberry. Indian Council of Agricultural Research, New Delhi, India.

Strand LL, 2008. Integrated pest management for strawberries (Vol. 3351), UCANR Publications, California, USA.

Trout TJ and J Gartung, 2004. Irrigation water requirements of strawberries. Proceedings of California Plant and Soil Conference 03 February - 04 February 2004, California, USA. Edited by: California Chapter of the American Society of Agronomy, pp. 54-59.

Yang J, B Li, and S Liu, 2000. A large weighing lysimeter for evapotranspiration and soil-water-groundwater exchange studies. Hydrologic Processes, 14: 1887-1897.

Young MH, PJ Wierenga, and FC Mancino, 1996. Large weighing lysimeters for water use and deep percolation studies. Soil Science, 161: 491-501. 